\title{
ОСНОВНІ ПСИХОПАТОЛОГІЧНІ ПРОЯВИ ПРОДРОМАЛЬНОГО ПЕРІОДУ ПСИХОЗУ
}

\author{
๑О. П. Венгер, О. Є. Смашна, Я. М. Несторович, Ю. І. Мисула,
} Л. М. Сас, В. С. Білоус, О. О. Люта, Т. П. Гусєва

ДВНЗ «Тернопільський державний медичний університет імені І. Я. Горбачевського МОЗ України»

РЕзюМЕ. Всесвітня психіатрична асоціація і Європейська асоціація психіатрів в якості основної стратегії лікування психозів загалом і шизофренії зокрема пропонують раннє виявлення цієї патології та своєчасне медичне втручання. Особливе значення надається ранньому втручанню у продромальному періоді психозу.

Мета дослідження - вивчення психопатологічних закономірностей розвитку продромальної стадії психозу для виявлення факторів ризику формування психозу. У процесі виконання дослідження були обстежені 137 пацієнтів з першим психотичним епізодом.

Результати. Найважливішими діагностичними ознаками продромального періоду психозу (ППП) у хворих на параноїдну шизофренію (ПШ) є стереотипне мислення, соціальна ізоляція, дезорганізаційні розлади мислення, пасивно-апатична соціальна відстороненість, підозріливість. Найінформативнішими продромальними симптомами ГП у хворих на ПШ є концептуальна дезорганізація мислення, хмерне мислення, соціальна ізоляція або усамітнення, підозріливість / персекуторні ідеї, зниження вираженості емоцій.

Висновки. Отримані дані дозволяють прогнозувати у пацієнтів з гострим поліморфним психотичним розладом (ГППР) меншу прогредієнтність психотичного розладу, його більш сприятливий перебіг і кращий вихід.

КЛЮЧОВІ СЛОВА: продромальний період психозу; параноїдна шизофренія; гострий поліморфний психотичний розлад.

Вступ. Всесвітня психіатрична асоціація і Європейська асоціація психіатрів в якості основної стратегії лікування психозів у цілому і шизофренії зокрема пропонують раннє виявлення цієї патології та своєчасне медичне втручання. Особливе значення надається ранньому втручанню у продромальному періоді психозу.

Мета дослідження - вивчення психопатологічних закономірностей розвитку продромальної стадії психозу для виявлення факторів ризику формування психозу.

Матеріал і методи дослідження. У процесі виконання дослідження були обстежені 137 пацієнтів з першим психотичним епізодом: 1) 65 пацієнтів (2-3 госпіталізація) - з діагнозом ПШ (F20.0); 2) 72 пацієнти (перша госпіталізація) - з діагнозом ГППР (F23.0, F23.1), які були обстежені як у форматі реального часу, так і ретроспективно.

Клініко-психопатологічні прояви продромального періоду психозу (ППП) у пацієнтів з параноїдною шизофренією (ПШ) та гострим поліморфним психотичним розладом (ГППР) були вивчені за допомогою шкали PANSS (ретроспективно) і шкали продромальних симптомів SOPS.

Результати й обговорення. За результатами аналізу вираженості і частоти позитивних і негативних симптомів ППП у хворих на ПШ та ГППР, можна констатувати, що у хворих на ПШ в ППП достовірно переважають розлади мислення, пасивно-апатична соціальна відстороненість, стереотипне мислення, підозріливість і емоційна відчуженість.

Розлади мислення у вигляді розірваності цілеспрямованого потоку думок, докладності, зі- сковзування, аморфності асоціацій, непослідовності, паралогічності, «закупорки» думок у сильному ступені вираженості реєструвалися у $26,2 \%$ випадків $(p<0,01)$.

Пасивно-апатична соціальна відстороненість (зниження інтересу, ініціативи, зменшення товариськості внаслідок пасивності, апатії, втрати енергії, безвілля) у стані середнього ступеня вираженості (пасивна участь пацієнта в невеликій кількості соціальних дій, без прояву інтересу та ініціативи, більшу частину часу проводить на самоті) виявлена у $30,8 \%$ пацієнтів $(p<0,05)$.

Стереотипне мислення виявлялося порушенням плавності, спонтанності і гнучкості мислення, ригідністю і повторюваністю розумових процесів у стані середнього ступеня вираженості і зазначалося у $30,8 \%$ пацієнтів $(p<0,05)$.

Підозріливість, страх переслідування помірного ступеня вираженості реєструвалися у $30,8 \%$ пацієнтів $(p<0,05)$.

Емоційна відчуженість у вигляді відсутності інтересу до подій, зниження залученості і причетності до них у помірному ступені вираженості виявлена у 40,0 \% пацієнтів $(p<0,01)$.

Аналіз інформативності виділених за допомогою шкали PANSS позитивних і негативних симптомів $(p<0,05$ і $p<0,01)$ в ППП у хворих ПШ представлений у таблиці 1.

Результати проведеного статистичного аналізу, представленого у таблиці 1, свідчать, що найбільш значущими інформативними клінічними ознаками ППП у хворих на ПШ $\epsilon$ : відсутність ознак тривожного стану (ДК-(-8,9), МІ-0,42, p<0,02), 
Огляди літератури, оригінальні дослідження, погляд на проблему, ювілеї дезорганізційні розлади мислення сильної та вище вираженості (ДК-(-4,20), МІ-0,38, p<0,005) та емоційна відчуженість помірної вираженості (ДК$(-3,45)$, Ml-0,38, p<0,003). Також важливими клінічними ознаками ППП у хворих на ПШ, що значно підвищують рівень діагностичної інформативності, $\epsilon$ :

підозріливість, страх переслідування помірної вираженості (ДК-(-3,01), МІ-0,24, p<0,02), стереотипне мислення середньої вираженості (ДК-(-2,66), MI-0,19, p<0,03), пасивно-апатична соціальна відстороненість середньої вираженості (ДК-(-2,66), MI-0,19, $\mathrm{p}<0,03)$.

Таблиця 1. Діагностичні коефіцієнти та міри інформативності виділених позитивних і негативних симптомів продромального періоду психозу у хворих на параноїдну шизофренію

(значення надано у порядку зменшення рівня інформативності)

\begin{tabular}{|c|c|c|c|}
\hline Симптоми & $\begin{array}{c}\text { Оцінка за шкалою } \\
\text { (бали) }\end{array}$ & ДК* & $\mathrm{Ml**}$ \\
\hline Тривожний стан (відсутність ознак) & 1 & $-8,9$ & 0,42 \\
\hline $\begin{array}{l}\text { Розлади мислення } \\
\text { (сильної та вище вираженості) }\end{array}$ & $\geq 6$ & $-4,20$ & 0,38 \\
\hline Емоційна відчуженість (помірної вираженості) & 4 & $-3,45$ & 0,38 \\
\hline Підозрілість, страх переслідування (помірної вираженості) & 4 & $-3,01$ & 0,24 \\
\hline Стереотипне мислення (середньої вираженості) & 5 & $-2,66$ & 0,19 \\
\hline Пасивно-апатична соціальна відстороненість (середньої вираженості) & 5 & $-2,66$ & 0,19 \\
\hline Загалом (сума за сукупністю ознак) & \multicolumn{2}{|l|}{24,88} & 1,8 \\
\hline
\end{tabular}

Примітки: 1. * - діагностичний коефіцієнт; 2. ** - міра інформативності Кульбака.

Згідно з результатами, представленими у таблиці 2, у хворих з ГППР в ППП достовірно переважали такі клініко-психопатологічні симптоми: га- люцинаторна поведінка, збудження, тривожний стан, напруженість, порушення уваги, неприродний вміст мислення.

Таблиця 2. Міра інформативності виділених позитивних і негативних симптомів у продромальному періоді психозу у хворих з гострим поліморфним психотичним розладом (значення надано у порядку зменшення рівня інформативності)

\begin{tabular}{|l|c|c|c|}
\hline \multicolumn{1}{|c|}{ Симптоми } & $\begin{array}{c}\text { Оцінка за } \\
\text { шкалою } \\
\text { (бали) }\end{array}$ & дк* & м** \\
\hline Неприродний вміст мислення (помірної та середньої вираженості) & $4-5$ & 3,63 & 0,33 \\
\hline Стереотипне мислення (відсутність ознак) & 1 & 5,20 & 0,28 \\
\hline Напруженість (середньої вираженості) & 5 & 3,12 & 0,28 \\
\hline Тривожний стан (середньої вираженості) & 5 & 3,17 & 0,26 \\
\hline Галюцинаторна поведінка (середньої вираженості) & 5 & 3,31 & 0,23 \\
\hline Порушення уваги (середньої вираженості) & 5 & 2,57 & 0,17 \\
\hline Збудження (середньої вираженості) & 5 & 2,57 & 0,14 \\
\hline Загалом (за сукупністю ознак) & \multicolumn{2}{|c|}{23,57} & 1,69 \\
\hline
\end{tabular}

Примітки: 1. *-діагностичний коефіцієнт; 2. **-міра інформативності Кульбака.

Тривожний стан середнього ступеня вираженості зафіксований у $31,9 \%$ випадків $(p<0,01)$.

Напруженість (зовнішні прояви страху, тривоги і хвилювання (скутість, тремор, серцебиття, значне потовиділення і невгамовність)) у стані середнього ступеня вираженості реєструвалася у $34,7 \%$ пацієнтів $(p<0,01)$.

Порушення уваги у вигляді розладу цілеспрямованості уваги, зниження концентрації, відволікання, труднощі у її контролі, підтримці, переключенні у середньому ступені вираженості виявлені у $30,6 \%$ випадків $(p<0,05)$.
Неприродний вміст мислення у помірному ступені вираженості реєструвався у 27,8 \% пацієнтів $(p<0,01)$.

Аналіз інформативності виділених за допомогою шкали PANSS позитивних і негативних симптомів $(p<0,05$ і $p<0,01)$ в ППП у хворих з ГППР представлений у таблиці 2.

Як свідчать результати проведеного статистичного аналізу, найінформативнішими клінічними ознаками ППП у хворих з ГППР $\epsilon$ : неприродний вміст мислення помірної та середньої вираженості (ДК-3,63, МІ-0,33, p<0,007), відсутність ознак сте- 
Огляди літератури, оригінальні дослідження, погляд на проблему, ювілеї

реотипного мислення (ДК-5,20, МІ-0,28, $\mathrm{p}<0,03)$, напруженість середньої вираженості (ДК-3,12, MI-0,28, $\mathrm{p}<0,01)$, тривожний стан середньої вираженості (ДК-3,17, МІ-0,26, р<0,05) та галюцинаторна поведінка середньої вираженості (ДК-3,31, MI-0,23, p<0,05). Наявність мінімум чотирьох з виділених ознак $\epsilon$ достатньою для достовірної диференціації ГППР за симптомами продрому на рівні $p \leq 0,05$. Також значущими для діагностики $\epsilon$ наступні ознаки: порушення уваги середньої вираженості (ДК-2,57, МІ-0,17, р<0,05) та збудження середньої вираженості (ДК-2,57, МІ-0,14, р<0,05), наявність яких підвищує рівень діагностичної інформативності.

У дослідженні аналіз інтенсивності та якісного складу продромальних симптомів психотичного розладу у хворих з ПШ та ГППР був проведений за допомогою шкали продромальних симптомів SOPS.

Згідно з результатами, у хворих на ПШ в ППП виявлено наявність позитивних симптомів (концептуальна дезорганізація і підозрілість) і негативних симптомів (соціальна ізоляція і зниження вираженості емоцій).

Аналіз позитивних симптомів показав, що концептуальна дезорганізація (розпливчасте, громіздке, стереотипне, непослідовне, ґрунтовне, паралогічне мислення з уповільненим перебі- гом думок, віддзеркалюваним у мові) у середньому ступені вираженості виявлена у 32,3 \% випадків $(p<0,01)$.

Підозріливість/персекуторні ідеї у вигляді надмірної стурбованості з приводу мотивації інших людей, недовіри, підозріливості, параноїдного мислення, прихованого (відкритого) недовірливого ставлення, нестійких, уривчастих маячних переконань, помітних при інтерв'ю, у помірному ступені вираженості реєструвалися у 30,8 \% паці$\epsilon$ нтів $(p<0,05)$.

Вивчення негативних симптомів свідчило про те, що соціальна ізоляція або усамітнення (мало друзів і близьких людей, надмірна соціальна тривога, що не зменшується при знайомстві і більше пов'язана з параноїдними страхами, незручність у присутності інших і наданням переваги самотності, рідкісна участь у соціальній діяльності) у середньому ступені вираженості (мало друзів, недовірливий до інших) зазначалося у пацієнтів ПШ в 33,8 \% випадків $(p<0,01)$. Зниження вираженості емоцій у цій групі виявлено у $33,8 \%$ випадків $(p<0,05)$.

Аналіз інформативності виділених за допомогою шкали SOPS продромальних симптомів гострого психозу $(p<0,05$ і $p<0,01)$ у хворих ПШ представлений у таблиці 3.

Таблиця 3. Міра інформативності виділених продромальних симптомів гострого психозу у хворих на параноїдну шизофренію (значення надано у порядку зменшення рівня інформативності)

\begin{tabular}{|c|c|c|c|}
\hline Симптоми & $\begin{array}{c}\text { Оцінка за шкалою } \\
\text { (бали) }\end{array}$ & ДК* & $\mathrm{Ml} * *$ \\
\hline Концептуальна дезорганізація (середньо та сильно виражена) & $5-6$ & $-4,06$ & 0,44 \\
\hline Вигадливе мислення (сумнівна наявність) & 2 & $-3,45$ & 0,29 \\
\hline Соціальна ізоляція або усамітнення (середнього ступеня) & 5 & $-3,08$ & 0,26 \\
\hline Підозріливість / персекуторні ідеї (помірного ступеня) & 4 & $-3,04$ & 0,24 \\
\hline Зниження вираженості емоцій (середнього ступеня та сильно виражене) & $5-6$ & $-2,38$ & 0,19 \\
\hline \multicolumn{2}{|l|}{ Загалом (за сукупністю ознак) } & 16,01 & 1,42 \\
\hline
\end{tabular}

Примітки: 1. * - діагностичний коефіцієнт; 2. ** - міра інформативності Кульбака.

Як свідчать результати проведеного статистичного аналізу, представлені у таблиці 3, найінформативнішими продромальними симптомами ГП у хворих на ПШ $\epsilon$ :

1) концептуальна дезорганізація мислення середнього та сильно вираженого ступенів (ДК-(-4,06), $\mathrm{MI}-0,44, \mathrm{p}<0,002)$;

2) сумнівна наявність вигадливого мислення (ДК-(-3,45), MІ-0,29, $\mathrm{p}<0,01)$;

3) соціальна ізоляція або усамітнення середнього ступеня (ДК-(-3,08), МІ-0,26, $p<0,01)$;

4) підозріливість / персекуторні ідеї помірного ступеня (ДК-(-3,04), МІ-0,24, p<0,05);

$5)$ зниження вираженості емоцій (ДК-(-8,49), MI-2,95, $\mathrm{p}<0,05)$.
Згідно з результатами дослідження, представленими у таблиці 4, у хворих з ГППР в ППП відзначалися позитивні симптоми дезорганізації і загальні симптоми.

Позитивні симптоми включали порушення перцепції/галюцинації середнього ступеня вираженості (спотворення перцепції, ілюзії, епізодичні галюцинації (псевдогалюцинації), які ще розпізнаються хворим, як нереальні, реєструвалися у $26,4 \%$ випадків $(p<0,01)$.

Симптоми дезорганізації виявлялися порушенням фокусування і уваги, а також химерним зниженням проблеми з фокусуванням і увагою (відмова від цілеспрямованої активності, що виявляється слабкою концентрацією, відволіканням, 
Огляди літератури, оригінальні дослідження, погляд на проблему, ювілеї

Таблиця 4. Міра інформативності виділених продромальних симптомів госторого психозу у хворих з гострим полеморфним психічним розладом (значення наведені у порядку зменшення рівня інформативності)

\begin{tabular}{|c|c|c|c|}
\hline Симптоми & $\begin{array}{l}\text { Оцінка за шкалою } \\
\text { (бали) }\end{array}$ & $Д K^{*}$ & $M I^{* *}$ \\
\hline Химерне мислення (помірного та середнього ступеня) & $4-5$ & 3,63 & 0,33 \\
\hline $\begin{array}{l}\text { Зниження толерантності до стресу (середнього та сильно } \\
\text { вираженого ступеня) }\end{array}$ & $5-6$ & 3,01 & 0,32 \\
\hline Розлади сну (середнього ступеня) & 5 & 3,54 & 0,27 \\
\hline Порушення перцепції/галюцинації (середнього ступеня) & 5 & 3,31 & 0,23 \\
\hline Проблема з фокусуванням та увагою (середнього ступеня) & 5 & 2,57 & 0,17 \\
\hline \multicolumn{2}{|l|}{ Загалом (за сукупністю ознак) } & 16,06 & 1,32 \\
\hline
\end{tabular}

Примітка: 1. * - діагностичний коефіцієнт; 2. ** - міра інформативності Кульбака.

труднощами у підтримці або у переміщенні фокусу уваги на нові стимули, неуважністю) у стані середнього ступеня вираженості зазначалося у $30,6 \%$ пацієнтів $(p<0,05)$.

Химерне мислення (мислення з дивними, фантастичними, алогічними і абсурдними ідеями) помірного ступеня вираженості виявлено у $27,8 \%$ випадків $(p<0,01)$.

Загальні симптоми реєструвалися у пацієнтів цієї групи у вигляді розладів сну і зниження толерантності до стресу.

Розлади сну (проблеми із засинанням, ранні пробудження і неможливість знову заснути, переривчастий сон з жахливими сновидіннями) у стані середнього ступеня вираженості відзначалися у $27,8 \%$ випадків $(p<0,01)$.

Зниження толерантності до стресу у вигляді виснаження стресогенною ситуацією, симптомів тривоги, афективної напруги, низької пристосовуваності у середньо-сильному ступені вираженості (надмірна реакція на звичайні щоденні події, які раніше легко долалися; легко перевантажується ситуаціями, які раніше легко переносилися) було виявлено у $43,1 \%$ пацієнтів $(p<0,01)$.
Аналіз інформативності виділених за допомогою шкали SOPS продромальних симптомів ГП $(p<0,05$ і $p<0,01)$ у хворих з ГППР представлений у таблиці 4.

За результатами проведеного статистичного аналізу, представленого у таблиці 4, найбільш достовірними продромальними симптомами ГП у хворих ГППР $\epsilon$ :

1) химерне мислення помірного та середнього ступеня (ДК-3,63, МІ-0,33, при р<0,007);

2) Зниження толерантності до стресу середнього та сильно вираженого ступеня (ДК-3,01, MI-0,32, при $\mathrm{p}<0,004)$;

3) розлади сну середнього ступеня (ДК-3,54, MI-0,27, при $\mathrm{p}<0,02$;

4) порушення перцепції / галюцинації середнього ступеня (ДК-3,31, МІ-0,23, при р<0,02);

5) проблеми з фокусуванням і увагою середнього ступеня (ДК-2,57, МІ-0,17, при р<0,03).

Наявність чотирьох з виділених ознак $\epsilon$ достатньою для достовірної диференціації продрому ГППР на рівні $p \leq 0,05$.

Динаміка вираженості груп симптомів хворих ПШ та ГППР в ППП представлена на рисунку 1.

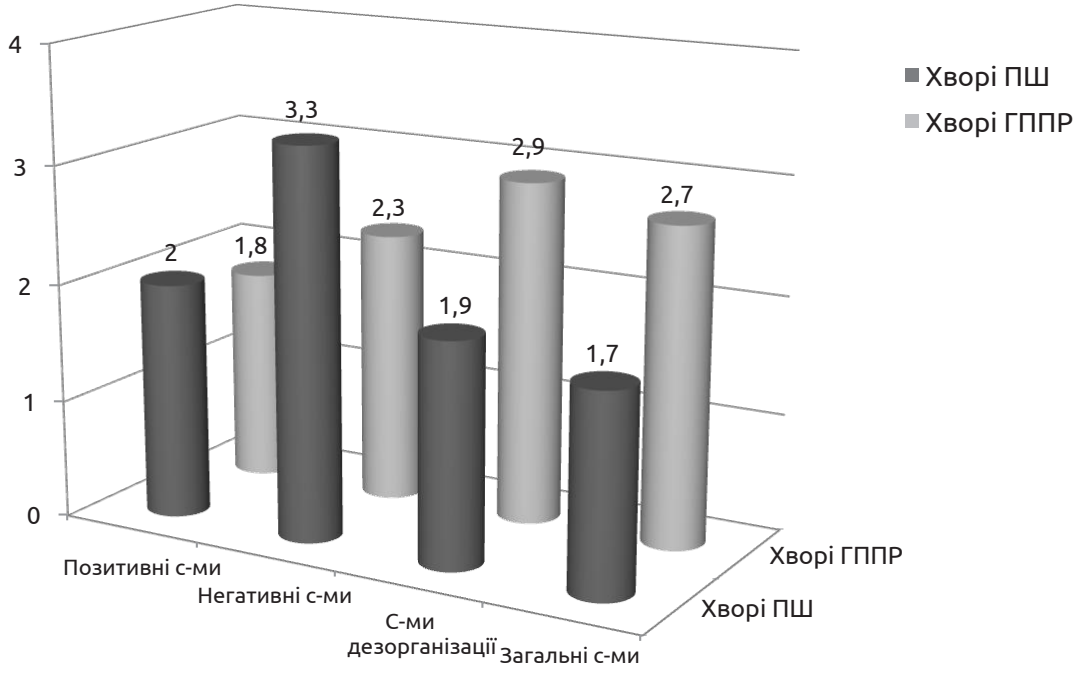

Рис. 1. Динаміка вираженості груп симптомів у хворих на параноїдну шизофренію та гострий поліморфний психічний розлад у продромальному періоді психозу. 
Огляди літератури, оригінальні дослідження, погляд на проблему, ювілеї

Як свідчать дані, представлені на рисунку 1, у хворих ПШ в ППП переважають негативні симптоми $-3,3 \pm 1,2$ бали $(p<0,05)$, тоді як у хворих ГППР у продромі психозу найбільш вираженими $\epsilon$ симптоми дезорганізації $(2,9 \pm 0,7$ бали, $p<0,05)$ і загальні симптоми $(2,7 \pm 1,3$ бали, $p<0,05)$.

У хворих на ПШ у продромі психозу переважають негативні симптоми, а у хворих з ГППР - симптоми дезорганізації і загальні симптоми і, на відміну від хворих з ПШ, у клініці продрому психозу хво- рих з ГППР відзначена менша частота таких симптомів як підозріливість, страх переслідування (персекуторні ідеі); концептуальна дезорганізація; стереотипне мислення; емоційна відчуженість і зниження вираженості емоцій; соціальна ізоляція або усамітнення; недостатність суджень і критики.

Висновки. Отримані дані дозволяють прогнозувати у пацієнтів з ГППР меншу прогредієнтність психотичного розладу, його більш сприятливий перебіг і кращий вихід.

\section{ЛІТЕРАТУРА}

1. Абрамов В. А. Клинический анализ инициального продрома шизофрении во временном и гендерновозрастном аспектах / В. А. Абрамов, О. И. Лихолетова, Г. Г. Путятин // Журнал психиатрии и медицинской психологии. - 2012. - № 2 (29). - С. 15-29.

2. Скугаревская М. М. Продром шизофрении. Оценка риска развития психоза / М. М. Скугаревская // Психиатрия. - 2009. - № 4 (06). - С. 71-79.

3. Preventing progression to first-episode psychosis in early initial prodromal states / A. Bechdolf, M. Wagner, S. Ruhrmann [et al.] // Br. J. Psychiatry. - 2012. - No. 200. - P. 22-29.

4. Neuropsychological profiles in different at-risk states of psychosis: executive control impairment in the early and additional memory dysfunction in the late-prodromal state / I. Frommann, R. Pukrop, J. Brinkmeyer [et al.] // Schizophr. Bull. - 2011. - Vol. 37 (4). - P. 861-873.

\section{REFERENCES}

1. Abramov, V.A., Likholetova, O.I., \& Putyatin, G.G. (2012). Klinicheskiy analiz initsialnogo prodroma shizofrenii vo vremennom i genderno-vozrastnom aspektakh [Clinical analysis of the initial prodroma of schizophrenia in the temporal and gender-age aspects]. Zhurnal psikhiatrii $i$ meditsinskoy psikhologii - Journal of Psychiatry and Medical Psychology, 2 (29), 15-29 [in Russian].

2. Skugarevskaya, M.M. (2009). Prodrom shizofrenii. Otsenka riska razvitiya psikhoza [Prodrom schizophrenia. Estimation of the risk of psychosis]. Psikhiatriya - Psychiatry, 4 (06), 71-79 [in Russian].

3. Bechdolf, A., Wagner, M., Ruhrmann, S., Harrigan, S., Putzfeld, V., Pukrop, R. et al. (2012). Preventing progression to first-episode psychosis in early initial prodromal states. Br. J. Psychiatry, 200, 22-29.

4. Frommann, I., Pukrop, R., Brinkmeyer, J., Bechdolf, A., Ruhrmann, S., Berning, J, ... \& Wagner, M. (2011). Neuropsychological profiles in different at-risk states of psychosis: executive control impairment in the early and additional

5. Cognitive functioning in prodromal psychosis: a meta-analysis / P. Fusar-Poli, G. Deste, R. Smieskova [et al.] // Arch. Gen. Psychiatry. - 2012. - Vol. 69. - P. 562-571.

6. Lessons learned from the psychosis high-risk state: towards a general staging model of prodromal intervention / P. Fusar-Poli, A. R. Yung, P. McGorry [et al.] // Psychol. Med. - 2014. - Vol. 44. - P. 17-24.

7. Elevated striate dopamine function linked to prodromal signs of schizophrenia / O. Howes, A. Montgomery, M. Asselin [et al.] // Arch. Gen. Psychiatry. - 2009. - Vol. 66. P. 13-20.

8. Course of neurocognitive deficits in the prodrome and first episode of schizophrenia / C. Jahshan, R. K. Heaton, S. Golshan, K. S. Cadenhead // Neuropsychology. - 2010. Vol. 24 (1). - P. 109-120.

memory dysfunction in the late-prodromal state. Schizophr. Bull., 37 (4), 861-873.

5. Fusar-Poli, P., Deste, G., Smieskova, R., Barlati, S., Yung, A.R., Howes, O., ... \& Borgwardt, S. (2012). Cognitive functioning in prodromal psychosis: a meta-analysis. Arch. Gen. Psychiatry, 69, 562-571.

6. Fusar-Poli, P., Yung, A.R., McGorry, P., \& van Os, J. (2014). Lessons learned from the psychosis high-risk state: towards a general staging model of prodromal intervention. Psychol. Med., 44, 17-24.

7. Howes, O., Montgomery, A., Asselin, M., Murray, R.M., Valli, I., Tabraham, P., ... \& Grasby, P.M. (2009). Elevated striate dopamine function linked to prodromal signs of schizophrenia. Arch. Gen. Psychiatry, 66, 13-20.

8. Jahshan, C., Heaton, R.K., Golshan, S., \& Cadenhead, K.S. (2010). Course of neurocognitive deficits in the prodrome and first episode of schizophrenia. Neuropsychology, 24 (1), 109-120. 


\title{
Огляди літератури, оригінальні дослідження, погляд на проблему, ювілеї
}

\section{ОСНОВНЫЕ ПСИХОПАТОЛОГИЧЕСКИЕ ПРОЯВЛЕНИЯ ПРОДРОМАЛЬНОГО ПЕРИОДА ПСИХОЗА}

\author{
๑Е. П. Венгер, Е. Е. Смашна, Я. М. Нестерович, Ю. И. Мисула, Л. М. Сас, \\ В. С. Белоус, О. А. Люта, Т. П. Гусева
}

\author{
ГВУз «Тернопольский государственный медицинский университет имени И. Я. Горбачевского \\ МОЗ Украины»
}

РЕЗЮМЕ. Всемирная психиатрическая ассоциация и Европейская ассоциация психиатров в качестве основной стратегии лечения психозов в целом и шизофрении в частности предлагают раннее выявление этой патологии и своевременное медицинское вмешательство. Особое значение придается ранним вмешательством в продромальном периоде психоза.

Цель исследования - изучение психопатологических закономерностей развития продромальной стадии психоза для выявления факторов риска формирования психоза. В процессе выполнения исследования были обследованы 137 пациентов с первым психотическим эпизодом.

Результаты. Наиболее важными диагностическими признаками продромального периода психоза (ППП) у больных ПШ являются: стереотипное мышление, социальная изоляция, дезорганизационные расстройства мышления, пассивно-апатичная социальная отстраненность, подозрительность. Наиболее информативными в продроме симптомами ОП у больных ПШ являются: концептуальная дезорганизация мышления, вычурное мышление, социальная изоляция или уединение, подозрительность/персекуторные идеи, снижение выраженности эмоций.

Выводы. Полученные данные позволяют прогнозировать у пациентов с острым полиморфным психическим расстройством (ОППР) меньшую прогредиентность психотического расстройства, его более благоприятное течение и лучший исход.

КЛЮЧЕВЫЕ СЛОВА: продромальный период психоза; параноидная шизофрения; острое полиморфное психотическое расстройство.

\section{MAIN PSYCHOPATHOLOGICAL MANIFESTATIONS IN THE PRODROMAL PERIOD OF PSYCHOSIS}

\author{
๑O. P. Venger, O. Ye. Smashna, Ya. M. Nestorovych, Y. I. Mysula, L. M. Sas, \\ V. S. Bilous, O. O. Liuta, T. P. Guseva \\ I. Horbachevsky Ternopil State Medical University
}

SUMMARY. The World Psychiatric Association and the European Association of Psychiatrists, as the main strategy for the treatment of psychosis in general and schizophrenia in particular, offer early detection of this pathology and timely medical intervention. Particular importance is given to early intervention in the prodromal period of psychosis.

The aim of the study - to learn the psychopathological patterns of the development of the prodromal stage of psychosis to identify the risk factors for the formation of psychosis. In the course of the study, 137 patients with the first psychotic episode were screened.

Results. The most important diagnostic features of the prodromal period of psychosis (PPP) in patients with paranoid schizophrenia are: stereotyped thinking, social isolation, disorganization thinking disorders, passive-apathy social isolation, suspicion. The most informative prodromal symptoms of acute psychosis in patients with acute polymorphic psychotic disorder are: conceptual disorganization of thinking, bizzare thinking, social isolation, suspicion / persecutory ideas, diminished expression of emotions.

Conclusions. The obtained data allows to predict in patients with acute polymorphic psychotic disorder (APPP) less progressivity of psychotic disorder, its more favorable course and the best way out.

KEY WORDS: prodromal period of psychosis; paranoid schizophrenia; acute polymorphic psychotic disorder.

Отримано 02.11.2018 